\title{
The problem of adaptation and evolution to overcome the COVID-19 epidemic for service quality of Hanoi old quarter hotels (During the period of the COVID- 19 epidemic)
}

\author{
Ha, Nguyen- Van and Nghia, Le Chi \\ Faculty of Business Administration \\ Banking Academy, Vietnam \\ Email: hanv@hvnh.edu.vn
}

\author{
Quoc, Dang-Nam \\ ESSCA School of Management \\ (Essca Grande Ecole), France; \\ Email: namquoc.dang@essca.eu
}

\begin{abstract}
This study examines the factors affecting the service quality of Hanoi old quarter hotels. The investigation results of 150 customers who have used accommodation services in the Hanoi old quarter. From there, analyze results and identify shortcomings and points that need to be overcome. Make the most intuitive conclusions to solve problems for hotel businesses here.
\end{abstract}

Index Terms-service quality, Hanoi old quarter hotel, COVID- 19 epidemic, hotel

\section{INTRODUCTION}

$\mathrm{T}$ HE HOSPITALITY and tourism industry is gradually becoming a critical spearhead economic sector, making a significant contribution to the country's overall economy. In recent years, the evolution of the accommodation service business has become exciting. According to figures, in 2019, Vietnam's tourism industry achieved a "golden" miracle of growth, welcoming more than 18 million international visitors, an increase of $16.2 \%$ compared to 2018 , serving $85 \%$ of domestic tourists, the number of tourists increased. The spike caused some places to have high occupancy, but overall, the average room capacity of the accommodation system decreased. [4]

With its position as the 'heart' of the country with advantages, potential, and greater responsibility than other localities, Hanoi increasingly asserts itself as one of the attractive destinations of the region and world. In recent years, Hanoi has been on the list of 1/7 nominations for "World's Leading Cities Destinations 2018" of World Travel Award -WTA, Traveler's Choice Awards 2019, and many other ratings. The problem for Hanoi is how to preserve and develop this "brand" sustainably. One of the most prominent features in Hanoi is the old quarter. It contains historical relics, the most beautiful landscapes, typical of Vietnamese folk architecture with the harmonious and lively combination of the overall architecture and the convenience in daily life were a surprise, bringing many experiences. They are significant benefits to attracting and retaining tourists for Hanoi. Although the old town has great potential, it has not been able to bring into full play its potential. While service providers want to improve service quality, add more rooms to meet growing demand, but still have to preserve the structure and ancient features of the Hanoi old quarters. [12]

This article explores the impact of the COVID- 19 epidemic on hospitality in the Hanoi old quarter, thereby pointing out the advantages and disadvantages facing the hospi- tality industry. The article uses quantitative methods and analysis, thereby giving results on the factors affecting the service quality of Hanoi old quarter hotels. These impacts both create opportunities for the hotels and cause them to face other challenges. The article also offers solutions that can help the Hanoi old quarter hotels to improve the service quality and overcome the crisis.

From analyzing the factors affecting the quality of hotel services in many aspects, thereby helping hotel managers and business owners understand the importance of each factor from which to have the most overview to allocate resources in each time and stage of business activities. Moreover, at the time of the study, when the Covid 19 epidemic was developing intensely both at home and abroad, it was helpful for changes in policies to overcome the pandemic.

\section{Literature ReView}

\section{A. Hotel}

To give a complete definition of a hotel, we first need to understand the history of the birth and development of the hotel from which to have a more comprehensive view of this concept.

The term hotel in Vietnamese or commonly known as Hotel is derived from the French word used to refer to a place that serves overnight guests, and it was introduced to our country in the early years of the twentieth century.

According to the American research group, "A hotel is where anyone can pay to rent a room to stay overnight. Each bedroom for rent inside must have at least two small rooms (bedroom and bedroom). Every other room has a bed, a phone, and a television. Other services, besides the bedroom service, can be offered, such as luggage transportation, a business center (including photocopying equipment), a restaurant, a bar, and various other forms of entertainment. Hotels can be constructed near or within business districts, resorts, or airports. According to Clause 12, Article 4 of the Law on Tourism of Vietnam, "Hotel is an establishment that rents out rooms and beds and provides other services to guests, and a hotel is a significant tourist accommodation establishment.

Although there are many different interpretations, it can be summarized as follows: a hotel is first and foremost a typical accommodation establishment built at a specific lo- 
cation and provides products and services to customers. Customers to make a profit

\section{B. Service quality}

A hotel business that wants to survive and grow in the market must guarantee that the objective is to attract and retain many clients while also ensuring and satisfying their demands. This necessitates firms paying close attention to service quality at all times. So, what exactly is service quality?

Up to now, there are many definitions of service that have been given in different ways.

- Services are intangible products produced and consumed at the same time. In the broad sense of marketing, a service is an intangible product. [13]

- Another definition, service is a process that includes behind-the-scenes and front-end activities, where customers and suppliers interact. Service is a highly intangible process. [14]

- Services are business transactions between service providers and customers with the ultimate aim of satisfying customers. [15]

- A service is any measure or advantage that one party can provide to the other that is mainly undetectable and does not result in appropriation. The performance of the service may or may not include the use of the commodities in their physical form. [16]

The hotel's products and services comprise two significant services and two extra services: the leading service is room service and food service to meet intense demands, while supplementary services are other services to satisfy secondary needs during their stay at the hotel. The appropriateness of a product or service to fulfill specified or predetermined client needs is referred to as service quality. In other words, service quality is the gap between customers' requests and services given; if the want surpasses the capacity to satisfy, the client is dissatisfied.

As a result, hotel service quality is measured by comparing the perceived volume and the expected quality of the hotel's offerings.

\section{Methodology}

\section{1) Sample}

The paper topic consists of 25 variables, so the minimum sample is 125 . Including the risk cases in case the reference participant does not answer, or the answer sheet is invalid, the actual sample of the interview will be 150 samples and collect 134 quality assurance votes, discarding 16 votes. The paper was conducted to evaluate the factors related to the quality of service delivery to customers in the Hanoi Old Quarter. The study's data are primary data collected from the distribution of votes to 150 customers who have used the service and are using the accommodation service in Hanoi Old Quarter. The paper uses the quantitative method to measure the quality of the service. The accommodation services are provided to customers in the old quarter of Hanoi. Through seminars to meet business enterprises, hotel service groups on social networks, and through the help of brothers, friends, and instructors, we have sent 150 direct or email surveys to accommodation businesses in Hanoi Old Quarter via Google Forms tool, served April and May 2020 in Viet- nam. After two months, we got 134 answers with a response rate of $89.3 \%$

\section{2) Measures}

Based on the research model proposed earlier and information from previous research, along with the additions appropriate to the research situation in Vietnam, we develop the scale of the six impact factors, including Tangibility, Reliability, Responsiveness, Confidence, Communication, satisfaction [8][1][9]

We use 5-point Likert-type scales with the following marks: 1 is disagree, 2 is not agree, 3 is neutral, 4 is agree, and 5 is completely agree.

TABLe I: The SCALE USED For the Study[13]

\begin{tabular}{|l|l|}
\hline & Dimension Scale item \\
\hline & Tangibility \\
\hline HH1 & The front desk was visually appealing \\
\hline HH2 & The employees had clean, neat uniforms \\
\hline HH3 & The restaurant's atmosphere was inviting \\
\hline HH4 & The shops were pleasant and attractive \\
\hline HH5 & The outdoor surroundings were visually attractive \\
\hline HH6 & The hotel was bright and well lighted \\
\hline HH7 & The hotel's interior and exterior were well maintained \\
\hline HH8 & The hotel was clean \\
\hline & Reliability \\
\hline TC1 & My reservation was handled efficiently \\
\hline TC2 & My guest room was ready as promised \\
\hline TC3 & $\begin{array}{l}\text { TV, radio, A/C, lights, and other mechanical equipment } \\
\text { worked properly }\end{array}$ \\
\hline TC4 & I got what I paid for \\
\hline & Responsiveness \\
\hline PH1 & Employees responded promptly to my requests \\
\hline PH2 & Informative literature about the hotel was provided \\
\hline PH3 & Employees were willing to answer my questions \\
\hline PH4 & Employees responded quickly to solve my problems \\
\hline PH5 & Room service was prompt \\
\hline & Confidence \\
\hline TT1 & Employees knew about local places of interest \\
\hline TT2 & Employees treated me with respect \\
\hline TT3 & Employees were polite when answering my questions \\
\hline TT4 & The hotel provided a safe environment \\
\hline TT5 & The facilities were conveniently located \\
\hline & Communication \\
\hline GT1 & Charges on my account were clearly explained \\
\hline GT2 & I received undivided attention at the front desk \\
\hline GT3 & Reservationists tried to find out my particular needs \\
\hline GT4 & Employees anticipated my needs \\
\hline
\end{tabular}

\section{Results}

\section{A. Reliability analysis}

Cronbach's Alpha is a measure of the scale's reliability. Using Cronbach's Alpha, unsuitable variables are removed. All scales are eligible since their Cronbach's Alpha coefficients are more than 0.6. tangibility, with the exception of scale 4 , where the measurement of interest rates will be removed because it is unrelated to the scale.

The population's Cronbach's Alpha coefficient of 0.825 is notable, ranging from 0.6 to 1 .

The variable correlation coefficient - total (Corrected Item-Total Correlation) of observable variables $\mathrm{HH} 1, \mathrm{HH}$, 
HH3, HH4, HH5, HH6, HH7 is $0.610 ; 0.682 ; 0.409 ; 0.532$; $0.641 ; 0.628 ; 0.470$ is larger than 0.3 , so the scale is standard and accurate.

\section{1) Reliability}

The Cronbach's Alpha coefficient of the population 0.766 ranges from 0.6 to 1 , which is significant.

The variable correlation coefficient - total (Corrected Item-Total Correlation) of observable variables TC1, TC2, TC3, TC4 is 0.539 , respectively; $0.585 ; 0.586 ; 0.553$ are all greater than 0.3 , so the scale is standard and accurate.

\section{2) Responsiveness}

The Cronbach's Alpha coefficient of the population 0.803 ranges from 0.6 to 1 , which is significant.

The variable correlation coefficient - total (Corrected Item-Total Correlation) of observable variables $\mathrm{PH} 1, \mathrm{PH} 2$, $\mathrm{PH} 3$, PH4,PH5,PH6 is 0.624 , respectively; 0.567; 0.650; $0.439 ; 0.533 ; 0.545$ are all greater than 0.3 , so the scale is standard and accurate

3) Confidence

The Cronbach's Alpha coefficient of the population 0.700 ranges from 0.6 to 1 , which is significant.

The variable correlation coefficient - total (Corrected Item-Total Correlation) of observable variables TT1, TT2, TT3, TT4 is 0.445 , respectively; $0.556 ; 0.465 ; 0.490$ are all greater than 0.3 , so the scale is standard and accurate.

4) Communication

The Cronbach's Alpha coefficient of the population 0.664 ranges from 0.6 to 1 , which is significant.

The correlation coefficient - total (Corrected Item-Total Correlation) of the observed variables GT1, GT2, GT3, GT4 is 0.3450 .448 , respectively; $0.580 ; 0.420$ are all greater than 0.3 , so the scale is standard and accurate.

4.2 Identify influencing factors by the Exploratory Factor Analysis (EFA)

The observed variables used to quantify the features of each element that impact the customer's usage of predatory loans will be evaluated after examining the Cronbach's Alpha reliability coefficient. Components' factor analysis with varimax rotation was used to examine the possible dimensionality of variables. The correlation matrix for all variables evaluated was correlated by KMO (to verify the suitability of factor analysis), resulting in $0.876(>0.5)$, and Bartlett's Test of Sphericity showed that variables utilized in this research are unrelated with the Sig 0,05. This implies that EFA is relevant to the data.

Table III: KMO and Bartlett's Test

\begin{tabular}{|l|l|c|}
\hline \multicolumn{2}{|l|}{$\begin{array}{l}\text { Kaiser-Meyer-Olkin Measure of sampling Ad- } \\
\text { equacy }\end{array}$} & .876 \\
\hline \multirow{2}{*}{$\begin{array}{l}\text { Bartlett's Test of } \\
\text { Sphericity }\end{array}$} & Approx. Chi-Square & 1258.756 \\
\cline { 2 - 3 } & df & 300 \\
\cline { 2 - 3 } & Sig. & .000 \\
\hline
\end{tabular}

Through checking the necessary conditions to carry out the EFA analysis method, it shows that: the correlation matrix for all the variables tested for correlation by $\mathrm{KMO}$ is $0.876>0.5$, proving that the factor analysis is appropriate with research data. In addition, the result of Bartlett's test is 1258,756 with the sig significance level of $0.000<0.5$, so it is sufficient to reject the hypothesis Ho, so the data collected using the factor analysis method is entirely appropriate.
TABLE IV:

\begin{tabular}{|c|c|c|c|c|c|c|}
\hline & \multicolumn{6}{|c|}{ Component } \\
\hline & 1 & 2 & 3 & 4 & 5 & 6 \\
\hline $\mathrm{HH} 2$ & .735 & & & & & \\
\hline HH5 & .696 & & & & & \\
\hline $\mathrm{HH} 4$ & .694 & & & & & \\
\hline HH1 & .691 & & & & & \\
\hline HH6 & .635 & & .392 & & & \\
\hline HH3 & .603 & & -.319 & & & \\
\hline PH6 & & .622 & & & & \\
\hline PH5 & .322 & .594 & & & & \\
\hline PH1 & & .549 & & .371 & & \\
\hline TT4 & & .539 & & & .430 & \\
\hline TC1 & & .536 & .462 & & & \\
\hline TC2 & & & .751 & & & \\
\hline TC3 & & & .638 & & & \\
\hline PH2 & & .399 & .511 & & & \\
\hline PH3 & & .431 & .470 & .332 & & \\
\hline GT1 & & & & .694 & & \\
\hline GT2 & & & & .690 & & \\
\hline PH4 & & .479 & & .523 & & \\
\hline TC4 & .320 & & .435 & .494 & & \\
\hline TT1 & & & & & .728 & .371 \\
\hline TT3 & & & & & .692 & \\
\hline HH7 & .533 & & & & .552 & \\
\hline TT2 & & .364 & .341 & & .487 & \\
\hline GT4 & & & & & & .814 \\
\hline GT3 & & & & .335 & & .727 \\
\hline $\mathrm{HH} 2$ & .735 & & & & & \\
\hline
\end{tabular}

Principal Component Analysis was used as the extraction method.

Varimax with Kaiser Normalization is the rotation method used.

a. After seven iterations, the rotation converged. According to hair and ctg $(2009,116)$ Multivariate Data Analysis, Prentice Hall International, Inc, Factor loading is the criterion to ensure the practical significance of EFA

+ , If $0.3=$ Factor loading $=0.4$ is considered to have reached the minimum level

+ , If Factor loading $>=0.5$ is considered practical significance Looking at the Rotated Component Matrix table above, there are 6 columns, indicating that there are 6 factors generated from 25 independent variables, and 12 variables with unacceptable factor loading: TT2, HH7, TC4, PH4, PH3, PH2, TC1, PH5, TT4, PH1, HH3, HH6. Due to ensure convergence value (Factor Loading load factors must be greater than 0.5 ) and ensure discriminant validity (In the same line, the difference between the greatest and secondlargest number must be more than 0.3 ); therefore, we delete

Table V: Total Variance Explained

\begin{tabular}{|l|l|l|l|}
\hline \multirow{2}{*}{ Component } & \multicolumn{3}{|l|}{ Initial Eigenvalues } \\
\cline { 2 - 4 } & Total & \% of Variance & Cumulative \% \\
\hline 1 & 4.041 & 31.086 & 31.086 \\
\hline 2 & 1.604 & 12.340 & 43.426 \\
\hline 3 & 1.216 & 9.357 & 52.783 \\
\hline 4 & 1.006 & 7.738 & 60.520 \\
\hline 5 & .855 & 6.577 & 67.098 \\
\hline 6 & .786 & 6.044 & 73.142 \\
\hline 7 & .661 & 5.088 & 78.231 \\
\hline 8 & .614 & 4.722 & 82.953 \\
\hline 9 & .581 & 4.469 & 87.422 \\
\hline 10 & .494 & 3.799 & 91.221 \\
\hline 11 & .431 & 3.314 & 94.535 \\
\hline 12 & .363 & 2.789 & 97.324 \\
\hline 13 & .348 & 2.676 & 100.000 \\
\hline
\end{tabular}


these variables from the list of variables on the "Factor Analysis" page and perform EFA with the remaining variables, yielding the value shown below. Results of the 2nd EFA analysis

TABLE VI:

\begin{tabular}{|l|l|l|l|}
\hline \multirow{2}{*}{ Component } & \multicolumn{3}{|l|}{ Extraction Sums of Squared Loadings } \\
\cline { 2 - 4 } & Total & \% of Variance & Cumulative \% \\
\hline 1 & 4.041 & 31.086 & 31.086 \\
\hline 2 & 1.604 & 12.340 & 43.426 \\
\hline 3 & 1.216 & 9.357 & 52.783 \\
\hline 4 & 1.006 & 7.738 & 60.520 \\
\hline 5 & & & \\
\hline 6 & & & \\
\hline 7 & & & \\
\hline 8 & & & \\
\hline 9 & & & \\
\hline 10 & & & \\
\hline 11 & & & \\
\hline 12 & & & \\
\hline 13 & & & \\
\hline
\end{tabular}

TABLE VII:

\begin{tabular}{|l|l|l|l|}
\hline \multirow{2}{*}{ Component } & \multicolumn{3}{|l|}{ Rotation Sums of Squared Loadings } \\
\cline { 2 - 4 } & Total & \% of Variance & Cumulative \% \\
\hline & 2.436 & 18.736 & 18.736 \\
\hline 1 & 2.022 & 15.558 & 34.294 \\
\hline 2 & 1.876 & 14.431 & 48.725 \\
\hline 3 & 1.533 & 11.795 & 60.520 \\
\hline 4 & & & \\
\hline 5 & & & \\
\hline 6 & & & \\
\hline 7 & & & \\
\hline 8 & & & \\
\hline 9 & & & \\
\hline 10 & & & \\
\hline 11 & & & \\
\hline
\end{tabular}

\section{B. Results of factor analysis}

Recognizing and removing several ineligible variables that are TT2, HH7, TC4, PH4, PH3, PH2, PH5, TC1, TT4, PH1, HH3, HH6, we get a cumulative $\%$ of $60.520 \%$, or these 4 factors can explain $60,520 \%$ variation of observed variables or data.

After rotating the model for the second time, we can regroup the factors as follows:

Factor 1: includes 4 observed variables

HH4: The interior is conveniently arranged

$\mathrm{HH} 1$ : The reception desk is attractively arranged

HH5: Clean hotel

$\mathrm{HH}$ 2: Clean staff, neat uniforms

2nd multiplier: includes 2 observed variables

TT3: The staff is polite when answering my questions

TT1: Employees know about local attractions

The third factor: includes 2 observed variables

TC2: My room is ready as promised

TC3: TVs, radios, A/Cs, lights, and other devices work correctly and efficiently

Factor 4: including 1 observed variable

PH6: Room service is speedy

Factor 5: includes 4 observed variables

GT4: Employees anticipate my needs

GT3: The front desk staff went out of their way to understand my specific needs

GT1: My bill is clearly explained

GT2: I was given a fair reception.
Regardless of the front desk realizing the close relationship between the variables, these factors are considered factors affecting the quality of accommodation service provision.

TABLE VIII:

\begin{tabular}{|c|c|c|c|c|c|c|}
\hline & \multicolumn{6}{|c|}{ Component } \\
\hline & 1 & 2 & 3 & 4 & 5 & 6 \\
\hline $\mathrm{HH} 2$ & .735 & & & & & \\
\hline HH5 & .696 & & & & & \\
\hline HH4 & .694 & & & & & \\
\hline HH1 & .691 & & & & & \\
\hline HH6 & .635 & & .392 & & & \\
\hline $\mathrm{HH} 3$ & .603 & & -.319 & & & \\
\hline PH6 & & .622 & & & & \\
\hline PH5 & .322 & .594 & & & & \\
\hline PH1 & & .549 & & .371 & & \\
\hline TT4 & & .539 & & & .430 & \\
\hline $\mathrm{TC} 1$ & & .536 & .462 & & & \\
\hline TC2 & & & .751 & & & \\
\hline TC3 & & & .638 & & & \\
\hline PH2 & & .399 & .511 & & & \\
\hline PH3 & & .431 & .470 & .332 & & \\
\hline GT1 & & & & .694 & & \\
\hline GT2 & & & & .690 & & \\
\hline PH4 & & .479 & & .523 & & \\
\hline TC4 & .320 & & .435 & .494 & & \\
\hline TT1 & & & & & .728 & .371 \\
\hline TT3 & & & & & .692 & \\
\hline HH7 & .533 & & & & .552 & \\
\hline TT2 & & .364 & .341 & & .487 & \\
\hline GT4 & & & & & & .814 \\
\hline GT3 & & & & .335 & & .727 \\
\hline $\mathrm{HH} 2$ & .735 & & & & & \\
\hline
\end{tabular}

Principal Component Analysis is the extraction method used.

Varimax rotation with Kaiser normalization.

a. After 5 repetitions, the rotation converged.

\section{Results of factor analysis}

The regression method shows the relationship of challenge factors affecting the quality of accommodation service provision in the Old Quarter area as follows:

\section{$\mathrm{M}=\mathrm{B} 1 \mathrm{~N} 1+\mathrm{B} 2 \mathrm{~N} 2+\mathrm{B} 3 \mathrm{~N} 3+\mathrm{B} 4 \mathrm{~N} 4+\mathrm{B} 5 \mathrm{~N} 5$}

TABLE IX:

\begin{tabular}{|c|c|c|}
\hline $\mathrm{N}$ & \multirow{3}{*}{$\begin{array}{l}\text { Effects related to Tangibles } \\
\text { Influences related to Credibility }\end{array}$} & \\
\hline 1 & & \\
\hline $2^{\mathrm{N}}$ & & $\begin{array}{l}\text { Tổng của } 2 \text { biến quan } \\
\text { sát }\end{array}$ \\
\hline \begin{tabular}{ll|} 
& $\mathrm{N}$ \\
3 & \\
\end{tabular} & Effects related to Feedback & $\begin{array}{l}\text { Tống của } 1 \text { biến quan } \\
\text { sát }\end{array}$ \\
\hline $4^{\mathrm{N}}$ & $\begin{array}{l}\begin{array}{l}\text { Influences related to Confi- } \\
\text { dence }\end{array} \\
\end{array}$ & $\begin{array}{l}\text { Tổng của } 2 \text { biến quan } \\
\text { sát }\end{array}$ \\
\hline \begin{tabular}{ll|} 
& $\mathrm{N}$ \\
5 & \\
\end{tabular} & $\begin{array}{l}\text { Influences related to Communi- } \\
\text { cation }\end{array}$ & $\begin{array}{l}\text { Tống của } 4 \text { biến quan } \\
\text { sát }\end{array}$ \\
\hline $\mathrm{M}$ & $\begin{array}{l}\text { Impact on the quality of accom- } \\
\text { modation service provision in the } \\
\text { Old Quarter on customer satisfac- } \\
\text { tion }\end{array}$ & $\begin{array}{l}\text { Tổng của } 3 \text { biến quan } \\
\text { sát }\end{array}$ \\
\hline
\end{tabular}

To guarantee that the regression model analysis is carried out appropriately, the relationship between the dependent and independent variables and the relationship between the components must be tested. The regression analysis will be 
done if there is a correlation between the independent and dependent variables but no correlation between the independent variables.

TABLE X: CORRELATION ANALYSIS RESUltS

\begin{tabular}{|c|c|c|c|c|c|c|c|}
\hline & & N1 & N2 & N3 & N4 & N5 & $\mathrm{M}$ \\
\hline \multirow[t]{3}{*}{ N1 } & $\begin{array}{l}\text { Pearson } \\
\text { Correlation }\end{array}$ & 1 & $.392 * *$ & $.267 * *$ & $.265 * *$ & $.308 * *$ & $.556 * *$ \\
\hline & $\begin{array}{l}\text { Sig. (2- } \\
\text { tailed) }\end{array}$ & & .000 & .002 & .002 & .000 & .000 \\
\hline & $\mathrm{N}$ & 135 & 135 & 135 & 135 & 135 & 135 \\
\hline \multirow[t]{3}{*}{ N2 } & $\begin{array}{l}\text { Pearson } \\
\text { Correlation } \\
\end{array}$ & $.392 * *$ & 1 & $.366^{* *}$ & $.401 * *$ & $.410 * *$ & $.351 * *$ \\
\hline & $\begin{array}{l}\text { Sig. (2- } \\
\text { tailed) }\end{array}$ & .000 & & .000 & .000 & .000 & .000 \\
\hline & $\mathrm{N}$ & 135 & 135 & 135 & 135 & 135 & 135 \\
\hline \multirow[t]{3}{*}{ N3 } & $\begin{array}{l}\text { Pearson } \\
\text { Correlation }\end{array}$ & $.267 * *$ & $.366^{* *}$ & 1 & $.261 * *$ & $.440 * *$ & $.359 * *$ \\
\hline & $\begin{array}{l}\text { Sig. (2- } \\
\text { tailed) }\end{array}$ & .002 & .000 & & .002 & .000 & .000 \\
\hline & $\mathrm{N}$ & 135 & 135 & 135 & 135 & 135 & 135 \\
\hline \multirow[t]{3}{*}{ N4 } & $\begin{array}{l}\text { Pearson } \\
\text { Correlation }\end{array}$ & $.265^{* *}$ & $.401 * *$ & $.261 * *$ & 1 & $.288 * *$ & $.222 * *$ \\
\hline & $\begin{array}{l}\text { Sig. (2- } \\
\text { tailed) }\end{array}$ & .002 & .000 & .002 & & .001 & .010 \\
\hline & $\mathrm{N}$ & 135 & 135 & 135 & 135 & 135 & 135 \\
\hline \multirow[t]{3}{*}{ N5 } & $\begin{array}{l}\text { Pearson } \\
\text { Correlation }\end{array}$ & $.308^{* *}$ & $.410 * *$ & $.440^{* *}$ & $.288^{* *}$ & 1 & $.476^{* *}$ \\
\hline & $\begin{array}{l}\text { Sig. (2- } \\
\text { tailed) }\end{array}$ & .000 & .000 & .000 & .001 & & .000 \\
\hline & $\mathrm{N}$ & 135 & 135 & 135 & 135 & 135 & 135 \\
\hline \multirow[t]{3}{*}{$\mathrm{M}$} & $\begin{array}{l}\text { Pearson } \\
\text { Correlation }\end{array}$ & $.556^{* *}$ & $.351 * *$ & $.359 * *$ & $.222 * *$ & $.476^{* *}$ & 1 \\
\hline & \begin{tabular}{|l} 
Sig. (2- \\
tailed)
\end{tabular} & .000 & .000 & .000 & .010 & .000 & \\
\hline & $\mathrm{N}$ & 135 & 135 & 135 & 135 & 135 & 135 \\
\hline
\end{tabular}

The correlation between the independent variables of the person test has a sig value of $1(>0.05)$, so the hypothesis Ho is rejected, proving that the independent variables do not correlate with each other. From pearson results, see whether the model is stable or does not exist multicollinearity. From there, we continue to run the regression.

The conclusions of the regression model analysis to quantify the effects of the effect on the quality of housing service delivery in the Old Quarter are calculated using data from 134 research samples. The influencing factors are produced from the EFA analysis findings; each factor recovered using this factor analysis technique is determined as the average of the observed variables. - This study employed various linear regression analysis models with a one-pass input approach to examine the individual effect of each factor on visitor enjoyment and service quality (Enter). Thus, the six grouping parts indicated above are independent variables, and the influence on the quality of lodging service given on customer satisfaction is the independent variable (Dependent) that will be applied concurrently.

Synthetic results of the regression model

Table XI:Model Summary ${ }^{\mathrm{B}}$

\begin{tabular}{|l|l|l|l|l|}
\hline $\begin{array}{l}\text { Mode } \\
1\end{array}$ & $\mathrm{R}$ & $\begin{array}{l}\mathrm{R} \\
\text { Square }\end{array}$ & $\begin{array}{l}\text { Adjusted R } \\
\text { Square }\end{array}$ & $\begin{array}{l}\text { Std. Error of the } \\
\text { Estimate }\end{array}$ \\
\hline 1 & $.650 \mathrm{a}$ & .423 & .400 & .43454 \\
\hline
\end{tabular}

a. Predictors: (Constant), N5, N4, N1, N3, N2

b. Dependent Variable: $M$
Table XII:Result of ANOVA Test

\begin{tabular}{|l|l|l|l|l|l|}
\hline & $\begin{array}{l}\text { Sum of } \\
\text { Squares }\end{array}$ & df & $\begin{array}{l}\text { Mean } \\
\text { Square }\end{array}$ & F & Sig. \\
\hline Regression & 17.834 & 5 & 3.567 & 18.889 & $.000 \mathrm{~b}$ \\
\hline Residual & 24.359 & 129 & .189 & & \\
\hline Total & 42.193 & 134 & & & \\
\hline
\end{tabular}

a. Dependent Variable: $\mathrm{M}$

b. Predictors: (Constant), N5, N4, N1, N3, N2

The results also show that $\mathrm{R}$ Square $=0.423$, which explains $42.3 \%$ of the variation of the process affecting the quality of accommodation service provision through 5 factors that directly affect this process

\begin{tabular}{|c|c|c|c|c|}
\hline \multirow{2}{*}{\multicolumn{2}{|c|}{ Model }} & \multicolumn{2}{|c|}{$\begin{array}{l}\text { Unstandardized Coeffi- } \\
\text { cients }\end{array}$} & \multirow{2}{*}{$\begin{array}{l}\text { Standardized } \\
\text { Coefficients } \\
\text { Beta } \\
\end{array}$} \\
\hline & & B & Std. Error & \\
\hline \multirow[t]{6}{*}{1} & (Constant) & .616 & .357 & \\
\hline & N1 & .388 & .067 & .430 \\
\hline & N2 & .025 & .067 & .030 \\
\hline & N3 & .086 & .060 & .112 \\
\hline & N4 & -.015 & .072 & -.016 \\
\hline & N5 & .295 & .082 & .286 \\
\hline
\end{tabular}

TABLE XIV:

\begin{tabular}{|l|l|l|l|l|l|}
\hline \multicolumn{2}{|l|}{ Model } & $\mathrm{t}$ & \multirow{2}{*}{ Sig. } & \multicolumn{2}{l|}{ Collinearity Statistics } \\
\cline { 4 - 6 } \multicolumn{2}{|l}{1} & & & Tolerance & VIF \\
\hline & (Constant) & 1.724 & .087 & & \\
\cline { 2 - 6 } & $\mathrm{N} 1$ & 5.771 & .000 & .806 & 1.241 \\
\cline { 2 - 6 } & $\mathrm{N} 2$ & .371 & .711 & .675 & 1.482 \\
\cline { 2 - 6 } & $\mathrm{N} 3$ & 1.451 & .149 & .754 & 1.326 \\
\cline { 2 - 6 } & $\mathrm{N} 4$ & -.210 & .834 & .806 & 1.240 \\
\cline { 2 - 6 } & $\mathrm{N} 5$ & 3.618 & .000 & .715 & 1.399 \\
\hline
\end{tabular}

Among the factors affecting the quality of accommodation service provision in the Old Quarter area, the factor with the most impact is Tangible ( $\mathrm{b} 1=0.388$ ), followed by Communication factor $\mathrm{b} 4=0.295$ and the human factor. The least influential factor is Confidence $\mathrm{b} 4=-0.015$.

From this we can derive the following equation:

$\mathrm{M}=0.616+0.388 \mathrm{~N} 1+0.025 \mathrm{~N} 2+0.086 \mathrm{~N} 3-0.015 \mathrm{~N} 4+$ $0.295 \mathrm{~N} 5$

The factors affecting the quality of accommodation service provision in the Old Quarter area, the most significant influencing factor is tangible, but the factors related to communication also significantly affect the quality of accommodation services. The quality of accommodation service providers in the Old Quarter area, while the factors of confidence, responsiveness, and trustworthiness are also the factors that are predicted to contribute the most to the quality of the service provided. Accommodation services in the old town area, but all factors have low influence

\section{Discussion AND Limitations}

\section{A. Discussion}

The Getty et al. Lodgingquality .'s index scale of service quality is employed in this investigation. Consequently, the scales are being found, altered, and augmented, verifying the findings of previous researchers on service quality scales for the specific region and unit, namely transportation service.

The findings demonstrate that five characteristics influence excellent service: tangibility, dependability, responsiveness, confidence, and communication. 
Before writing the research paper, the hotel service in the old town was highly appreciated, but when the covid 19 pandemic broke out, it affected the world economy, the Vietnamese economy, and the service industry. Avoiding the heavy impact of the decline are confirmed on travelloka, ivivu, avia, traveler ... Seeing the big problem of the service industry, the author has written this study to point out the factors that affect the service industry, service quality,y, and some solutions. Due to the limitation of the article, there are many things that the author cannot specifically present here, and the author hopes to contribute something through the research to help the service industry overcome the pandemic.

\section{B. Limitations}

The study and research time are restricted; gathering client information will only take a month (April 2020), indicating that the coverage of the research issue has not been valued. To develop a more general quality scale for lodging service supply, a bigger sample size, more complex and professional methodologies, and a longer observation time are required. The study solely looked at the elements influencing the quality of lodging service provided because it had a short time frame and a restricted budget for implementation. There might be many more aspects not listed by the model, such as prestige, the hotel's reputation, the hotel care program, advertising, and so on. Hopefully, the subsequent research will go further.

\section{REFERENCES}

[1] Bello Yekini Ojo , Majebi enesi C. (2018). Lodging quality index approach: exploring the relationship between service quality and customer satisfaction in the hotel industry. Nigeria.

[2] Danh, N. T. (2018). Các yếu tố ảnh huởng đến chất luợng dịch vu lưu trú của hẹ thống khách sạn 3-5 sao tại TP Hồ Chí Minh. Hà Nội.

[3] Edmundas Jasinskas, Dalia Streimikerme , B. (2016). impact of hotel service quality on the loyalty of customers.

[4] Giang, T. (2020). 2019, du lịch Việt Nam đạt kỳ tích 'vàng' tăng trương.

[5] Grant Thornton. (2018). VietNam Hotel upscale Lodging- Hotel Survey 2018.

[6] Hà, L. T. (2008). Giải pháp nâng cao chất luợng dịch vụ phòng tại khách sạn Hoàng Hà. Hà Nội: Kinh tế.

[7] Hunter, V., \& Michl,J. (2000). Maximizing customer satisfaction and loyalty to drive growth and profitability. Velocity.

[8] Juliet M.Getty , RobertL.Getty. (2013). Lodging quality index assessing customer's perceptions of quality delivery.

[9] Parasurama A., Zeithaml V and Berry L. (1998). A multiple-item scale for measuring consumer perceptions of service quality. Journal of Retailing.

[10] Phan Chí Anh, N. N. (2013). Nghiên cưu các mô hình đánh giá chất luợng dịch vu . Hà Nội.

[11] Thanh Giang. (2019). Du lịch việt nam đạt kỳ tích 'Vàng' tăng truoơng. Hà Nội.

[12] Tạp Chí Tài Chính. (2017). Một số giải pháp phát triển ngành du lịch Việt Nam. Hà Nội: Kinh tế.

[13] Team Trilyo. (2018). service quality \& customer satisfaction in the hotel industry.

[14] Tổng Cục Thống Kê. (2019). Thông cáo báo chí về tình hình kinh tế xã hội quý IV năm 2019. Hà Nội.

[15] Principles of Marketing, Nguyen Dinh Tho-Nguyen Thi Mai Trang, 2008

[16] Bui Nguyen Hung, Nguyen Thuy Quynh Loan, 2004

[17] Ramaswamy, 1996

[18] Philip Koler, 2002 